\title{
An Experiment in the Transplantation of Plaice from the Barents Sea ("White Sea") to the North Sea.
}

\author{
By \\ George T. Atkinson, \\ Assistant Naturalist at the Lowestoft Laboratory.
}

About midnight on 26th June, 1908, at the close of a voyage to the White Sea fishing grounds, undertaken by Mr. A. E. Hefford and myself in the Hull steam trawler Princess Louise, $\mathrm{H}$ 837, Captain Turner of that vessel did me the great favour of taking a short haul to procure plaice for transplantation to the North Sea.

ObJect of the Experiment.-The object of this experiment was to test if it were possible for plaice to survive such physical changes as are necessarily involved in this great change of habitat, and to see further if they would display any feature of growth.

The result has been that not only do the fish appear to have survived, but they have grown in a most remarkable manner. The rate of growth shown by the last five specimens recaptured is much greater than that of North Sea plaice of the same sizes and sex, which have been marked in the same way and set out again on the grounds where they have been caught. The growth has been many times faster than that indicated by the otoliths of plaice in the portion of the Arctic Ocean from which they were brought.* This unusually rapid growth has been accompanied by considerable improvement of the fish as a marketable commodity.

The object of the voyage in the Princess Louise was to continue the investigations, commenced in the Roman, of the conditions of the plaice fishery in the Barents Sea. $\dagger$ It had been arranged to again accompany the Roman, H 948, but as Captain Leighton sailed a day earlier than was intended, he kindly arranged for $\mathrm{Mr}$. Hefford and

* As an illustration of the extremely slow growth which obtains in these northern waters, I have in my possession a photograph by my colleague, Mr. R. A. Todd, of ten otoliths of as many fish of the VIII group (in these cases fish just nine years old), five of these fish are from the North Sea and five from the Barents Sea ; 47, 48, 52, 52, and $54 \mathrm{~cm}$. were the lengths of the former, which were all mature females: the lengths of the latter three immature females and two mature males were only $30,30,32,27$, and $29 \mathrm{~cm}$.

† Journ. Mar. Biol. Assoc., VIII, 1908, ए. 71. 
myself to leave Hull with Captain Turner and to transfer to his own ship on the fishing grounds.

Unfortunately we were unable to meet as arranged, and this mishap deprived us of the use of two tanks which I had sent on board the Roman.* Had these been available a larger number of fish could have been as easily dealt with. To take the place of these tanks, there were improvised five tubs, made from halves of the casks which the trawlers take to sea for the reception of fish livers. Each of these was scrubbed out and filled with water to the depth of eighteen inches, holding in this manner 15-20 gallons apiece. Changes of water were effected by means of buckets and the use of the ship's hose at intervals. This primitive method was continued during the seven days occupied in steaming 1540 miles from the Barents Sea fishing grounds to the N.W. Rough of the Dogger, where the twenty-three surviving fish were marked and liberated.

A much larger number had originally been placed in these tubs, but owing to the very limited space available and the lack of means for adequately changing the water the mortality at first was very heavy.

We were fortunately favoured with moderate weather for the journey, except for some hours after coming out of the Norwegian fiords by the Lofoten Islands. Here the vessel, driven full speed in the face of a strong head wind, had the main deck frequently swept by the seas from the bows to the winch; however, the fish appeared to suffer no inconvenience and the tubs received no damage, being lashed on the after deck.

Besides my colleague Mr. A. E. Hefford, and Captain Turner, I have also to thank the chief engineer of the Princess Louise, Mr. Gardner, to whose resourcefulness in providing the tubs, and to whose interest, the successful issue of the experiment was in great measure due.

Changes of Temperature on the Voyage.-One of the most striking changes accompanying this journey south was naturally that of the temperature of the water in which the fish were being kept alive. On June 26th, on the fishing grounds, the bottom temperature varied between $34^{\circ}$ and $35^{\circ} \mathrm{F}$., whilst that of the surface was between $37^{\circ}$ and $38^{\circ} \mathrm{F}$. On June $27 \mathrm{th}$, before reaching Nordkyn, the temperature was between $40^{\circ}$ and $42 \cdot 3^{\circ} \mathrm{F}$., and on the 29 th, at Tromsö, had risen to $45^{\circ}$ and $47.0^{\circ}$, and reached $48.9^{\circ}$ on the 30 th, $49.5^{\circ}-52 \cdot 0^{\circ}$ on July 1st,

* I suggested to Captain Leighton that he should on the following voyage attempt to bring back some living plaice in these tanks, and brought to his notice the precautions to be observed to obtain a successful result. In correspondence he informs me that he left the White Sea fishing grounds with about sixty fish, of which forty-two were alive on his arrival at the Humber. These were then iced and finally distributed amongst the members of the crew.

NEW series. - vol. viri. No. 5. March, 1910. 


\section{AN EXPERINENT IN THE TRANSPLANTATION OF PLAICE FROM}

$54 \cdot 3^{\circ}-55 \cdot 7^{\circ}$ on the $2 \mathrm{nd}$, and on July $3 \mathrm{rd}$, up to the time of setting out the fish, the temperature had ranged between $54.5^{\circ}$ and $58.0^{\circ} \mathrm{F}$. The extremes of temperature these fish experienced thus ranged over $24^{\circ} \mathrm{F}$., without their appearing to have suffered from the rapidity with which the changes occurred.

RECAPTURE OF THE FISH.-The following table gives particulars of the recapture of the individual fishes (see next page).

The object in selecting the N.W. Rough as the point of liberation for these fish was that, in addition to being in the direct track of our vessel between the Norwegian and English coasts, it was a ground which offered a fair prospect of some of the fishes being returned if they survived. Unfortunately some Grimsby, Hartlepool, and Scarborough trawlers, engaged in fishing for cod and haddock, chanced at once to visit the area of liberation, and in the first month eight fish were returned. Five more being subsequently recaptured gives the result that within one year 13 or $56.5 \%$ have been returned.

The latter five were caught in the fourth (two specimens), seventh, tenth, and eleventh months after liberation, and without exception show important and unusually rapid growths compared with those which have been observed in the case of North Sea fish of corresponding size and sex.

These growths were accompanied by considerable improvement in the condition from the point of view of the market value of the fish.

Movements of the Fish.-A feature connected with the movements of the last five fish is that all but one had migrated from the deeper water (33 fms.) in which they were liberated, short distances on to the Dogger Bank (20 fms. and less).

The furthest migrant was E 3880 , which was taken on the Easternmost Shoal, about sixty miles from the point of liberation. Another fish, E 3876, had moved about forty miles in the direction of the Middle Rough and was retaken by a Dutch steam trawler. It is curious to note that the Grimsby trawler which effected the recapture of the former specimen also took, at the same spot, a plaice (E 778), which I had myself transplanted to the Dogger from the Dutch coast in May, 1907. This fish had grown $18.5 \mathrm{~cm}$.

All the female fish brought from the White Sea appeared to be immature, the contrast between such and spent ones, so soon after the northern spawning season, being in most cases very marked without internal examination being absolutely necessary.*

* A new feature in the biology of the plaice lies in the enormous depth at which the Barents Sea plaice spawn. In May, 1909, Captain Leighton informs me, they were found by our trawlers to be in spawning condition in great masses in 90 to 106 fathoms. 
TABLE I.

Table showing the particulars of liberation and recapture of the Plaice transplanted.

PARTICULARS OF LIBERATION.

July 3rd, 1908. 23 Plaice (E 3871-E 3893). Lat. $55^{\circ} 8^{\prime}$ N., $1^{\circ} 10^{\prime}$ E., 33 fms.

Transplanted from Barents Sea, Lat. $69^{\circ} 0^{\prime}$ s., $41^{\circ} 23^{\prime}$ E., 44 fms. ; carried 7 days in tubs ca. 1540 miles.

PARTICULARS OF RECAPTURE.

\begin{tabular}{|c|c|c|c|c|c|c|c|c|c|c|}
\hline $\begin{array}{c}\text { Date of } \\
\text { Recapture. }\end{array}$ & $\begin{array}{l}\text { No. of } \\
\text { Label. }\end{array}$ & Locality Reported. & $\begin{array}{l}\text { Depth } \\
\text { (fms.). }\end{array}$ & Caleulated Position. & $\begin{array}{l}\text { Vessel and } \\
\text { Port of Registry. }\end{array}$ & $\begin{array}{c}\text { Original } \\
\text { Length } \\
\text { (em.). }\end{array}$ & $\begin{array}{c}\text { Ultimate } \\
\text { Length } \\
\text { (em.). }\end{array}$ & $\begin{array}{l}\text { Weight } \\
\text { (grs.). }\end{array}$ & $\begin{array}{c}\text { Sex and } \\
\text { Maturity. }\end{array}$ & $\begin{array}{l}\text { No. of } \\
\text { Days at } \\
\text { Liberty. }\end{array}$ \\
\hline 1908 & & & & & & & & & & \\
\hline July 5 & E 3873 & Lat. $55^{\circ} 14^{\prime} \mathrm{N} ., 1^{\circ} 15^{\prime} \mathrm{E}$. & 40 & - & GY St. tr. & $37 \cdot 8$ & $36 \cdot 8$ & 491 & 9 & 2 \\
\hline,,$\quad 6$ & E 3887 & Lat. $55^{\circ} 0^{\prime} \mathrm{N} ., 1^{\circ} 0^{\prime} \mathrm{E}$. & 32 & - & SH St. tr. & $34 \cdot 7$ & $33 \cdot 8$ & 371 & $\delta$ & 3 \\
\hline,,$\quad 5-9$ & E 3889 & (Found on Pontoon, Grimsby) & $\overline{-1}$ & - & - & $35 \cdot 3$ & $34 \cdot 7$ & 309 & $\delta$ & ca. 4 \\
\hline ," 11 & E 3881 & Lat. $54^{\circ} 58^{\prime} \mathrm{N} ., 1^{\circ} 0^{\prime} \mathrm{E}$. & 31 & - & GY St. tr. & $40 \cdot 3$ & $39 \cdot 8$ & 446 & $\delta \mathrm{sp}$. & 8 \\
\hline 12 & E 3883 & Lat. $54^{\circ} 52^{\prime}$ N., $1^{\circ} 22^{\prime} \mathrm{E}$. & - & - & GY St. tr. & $35 \cdot 2$ & $34 \cdot 7$ & $353 \mathrm{~g}$ & @im. & 9 \\
\hline 13 & E 3874 & 75 miles $\mathrm{E} \frac{1}{2} \mathrm{~S}$ of Hartlepool & 30 & $54^{\circ} 54^{\prime} ., 0^{\circ} 53^{\prime} \mathrm{E}$. & HL St. tr. & $41 \cdot 7$ & $39 \cdot 4+$ & $523^{\circ}$ & ìm. & 10 \\
\hline,$\quad 20$ & E 3871 & 75 miles $\mathrm{E} \frac{1}{2} \mathrm{~S}$ of Hartlepool & $28-30$ & $54^{\circ} 54^{\prime},, 0^{\circ} 53^{\prime} \mathrm{E}$ & HL St. tr. & $35 \cdot 6$ & $35 \cdot 1$ & 407 & q im. & 17 \\
\hline, $24-26$ & E 3890 & (Found on Pontoon, Grimsby) & $\overline{-}$ & - & - & $33 \cdot 9$ & $33^{\circ} 0$ & $289 \mathrm{~g}$ & $\delta \mathrm{sp}$. & ca. 22 \\
\hline Nov. 6 & E 3876 & Lat. $55^{\circ} 20^{\prime}$ N., $2^{\circ} 20^{\prime}$ E. & 20 & - & Dutch St. tr. IJM & $34 \cdot 4$ & $38 \cdot 1$ & $590^{\circ}$ & 8 & 126 \\
\hline $\mathrm{b},, \quad 18$ & E 3880 & Lat. $54^{\circ} 39^{\prime}$ N., $2^{\circ} 45^{\prime}$ E. & 11 & - & GY St. tr. & $35 \cdot 8$ & $39 \cdot 6$ & 742 & 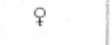 & 138 \\
\hline $\begin{array}{l}1909 \\
\text { Feb } \quad 27\end{array}$ & & & & & & & & & & \\
\hline $\begin{array}{ll}\text { Feb. } & 27 \\
\text { May } & 14\end{array}$ & $\begin{array}{l}\text { E } 3884 \\
\text { E } 3893\end{array}$ & $\begin{array}{l}\text { Lat. } 54^{\circ} 50^{\prime} \mathrm{N}, 1^{\circ} 5^{\prime} \mathrm{E} . \\
\text { Lat. } 54^{\circ} 57^{\prime} \mathrm{N}, 1^{\circ} 20^{\prime} \mathrm{E} \text {. }\end{array}$ & $\begin{array}{c}35 \\
18-20\end{array}$ & - & $\begin{array}{l}\text { GY St. tr. } \\
\text { GY St. tr. }\end{array}$ & $\begin{array}{l}43 \cdot 5 \\
33 \cdot 9\end{array}$ & $\begin{array}{l}47 \cdot 3 \\
39 \cdot 9\end{array}$ & $\begin{array}{c}1095 \mathrm{~g} \\
702\end{array}$ & osp. & $\begin{array}{l}239 \\
315\end{array}$ \\
\hline c June 20 & E 3875 & 105 miles N.E. from Spurn & $17-20$ & $55^{\circ} 5^{\prime}, 1^{\circ} 45^{\prime} \mathrm{E}$. & GY St. tr. & $42 \cdot 5$ & $50 \cdot 3$ & 1535 & 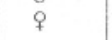 & 352 \\
\hline
\end{tabular}

NOTES.

(a). Very stale. Tail rays damaged, probable length, $41 \mathrm{~cm}$.

(b). Caught by same boat, on same day, and in same position as Plaice E 778. Apparently X years old.

(c). Very fat. Apparently commencing to mature for the first time. Noted "im. ?" on liberation.

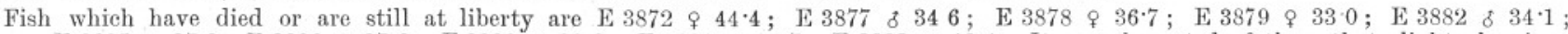
E 3885 o $37 \cdot 3$; E 3886 \& $27 \cdot 8$; E 3888 \& $39 \cdot 3$; E 3891 \& 35.7 ; E 3892 \% 46.4 . It may be noted of these that slight abrasions were noted at the time of liberation in seven instances (70\%). Similar abrasions were nevertheless noted in six instances, $46 \%$ of the fish which have already been recaptured. 
All the males, on the other hand, were above the average size at which this sex is found mature in the Barents Sea; two were actually found to be spent on being returned to the Laboratory after a few days of liberty. This fact makes the growth observed all the more a matter of surprise, as we usually find large male plaice grow very slowly. *

E 3884, caught in February, was observed to be recently spent, and had thus taken part in one reproductive period in the North Sea. The ovaries of E 3875 were such as one observes in female plaice which are apparently maturing for the first time.

On the basis of these last five fish, as discussed below, it would be absurd to attempt to base any definite conclusions. In discussing them, the main desire is to bring to notice the suggestive results that this small experiment has attained, so that when the opportunity again arises similar experiments may be attempted on a larger scale, since it can no longer be doubted that a rational development of the plaice fishery of the North Sea would be possible under a carefully planned scheme of transplantations.

Below have been drawn up a few notes on the changes of which the last five fish returned have given evidence, regarded from the following points of view :-

\section{Increase in size. \\ 2. Increase in weight. \\ 3. Increase in value.}

1. InCREase in Size.-The eight fish caught in July all show a slight shrinkage, as is usual in marked fishes retaken shortly after liberation. It is usual with some investigators to estimate shrinkage between death and remeasurement at $0.5 \mathrm{~cm}$., but in order to depress the observed growths rather than to exaggerate them this convention has been disregarded throughout.

The two specimens reported in November had increased in length from (male) 34.4 to $38 \cdot 1 \mathrm{~cm}$., and (female) 35.8 to $39 \cdot 6$, or $3 \cdot 7$ and 3.8 cm. respectively. The next fish was retaken in February, and the growth from 43.5 to $47 \cdot 3$, or $3.8 \mathrm{~cm}$., is a very rapid growth for such a large male. Another male fish came back in May, and had increased $6 \mathrm{~cm}$., from 33.9 to $39.9 \mathrm{~cm}$. The last fish returned gives an astonishing increase for so large a fish, having grown from 42.5 to 50.3 , or $7 \cdot 8 \mathrm{~cm}$. (female).

* It is interesting to note in comparison with this experiment, that Strodtmann transplanted plaice from the Baltic to the Elbe L.V., making the passage to the North Sea through the Kiel Canal. These were chiefly mature fish, and though many were retaken very few had grown at all after several months in their new surroundings. Cf. Reichard, Die deutschen Versuche mit gezeichneten Schollen II, p. 34. 
How rapid these individual growths are in comparison with those of the North Sea fish can be seen by reference to any published report. To illustrate this rapidity, a number of records have been taken from the English marking experiments in various localities in the North Sea. These have been put together in the form of a table, and fish have been chosen which mostly resemble the five White Sea plaice in original size, the sex being of necessity also the same.

At the head of each of five columns is given the label number of the White Sea plaice with its original size, growth, and number of days at liberty. Below each comes a list of North Sea fishes marked in the same way, and set out again in whatever part of the North Sea they happen to have been caught. Comparison can thus with ease be made by taking any of the North Sea fish and comparing the growth, or period at liberty, given at the top of the column :-

TABLE II.

Table showing growth in the periods stated of normal North Sea marked plaice to compare with five specimens transplanted from the Barents Sea.

\begin{tabular}{|c|c|c|c|c|c|c|c|c|c|}
\hline \multicolumn{2}{|c|}{$\begin{array}{c}\text { E } 3876 \text { of } 34 \cdot 4 \\
\text { grew } \\
3 \cdot 7 \mathrm{~cm} \text {. in } 126 \text { days. }\end{array}$} & \multicolumn{2}{|c|}{ 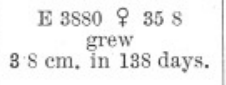 } & \multicolumn{2}{|c|}{$\begin{array}{c}\text { E } 3884 \text { of } 43.5 \\
\text { grew } \\
3.5 \mathrm{~cm} \text {. in } 239 \text { days. }\end{array}$} & \multicolumn{2}{|c|}{$\begin{array}{c}\text { E } 3893 \text { f } 33 \cdot 9 \\
\text { grew } \\
6 \cdot 0 \mathrm{~cm} . \text { in } 315 \text { days. }\end{array}$} & \multicolumn{2}{|c|}{$\begin{array}{c}\text { E } 3875 \text { \& } 42 \cdot 5 \\
\text { grew } \\
7.8 \mathrm{~cm} . \text { in } 352 \text { days. }\end{array}$} \\
\hline Growth. & Days out. & Growth. & Days out. & Growth. & Days out. & Growth. & Days out. & Growth. & Days out. \\
\hline 0.4 & 83 & $1 \cdot 7$ & 116 & 0.0 & 110 & 0.0 & 82 & 0.4 & 143 \\
\hline-0.4 & 136 & 0.9 & 119 & 0.2 & 142 & 0.8 & 97 & 0.1 & $\begin{array}{l}148 \\
176\end{array}$ \\
\hline $1 \cdot 4$ & 141 & $1 \cdot 0$ & 121 & 0.3 & 162 & $3 \cdot 5$ & 112 & $\begin{array}{l}0.1 \\
1.8\end{array}$ & $\begin{array}{l}197 \\
212\end{array}$ \\
\hline 1.0 & 142 & $1 \cdot 0$ & 154 & 0.8 & 230 & $2 \cdot 4$ & 119 & 11 & 234 \\
\hline 0.7 & 195 & $2 \cdot 5$ & 156 & 0.9 & 286 & 0.3 & 123 & $\begin{array}{l}0.7 \\
0.7\end{array}$ & $\begin{array}{l}282 \\
296\end{array}$ \\
\hline $1 \cdot 9$ & 196 & $1 \cdot 0$ & 183 & $1 \cdot 3$ & 293 & 0.6 & 142 & 16 & 314 \\
\hline $1 \cdot 0$ & 252 & $1 \cdot 8$ & 193 & 0.3 & 314 & $2 \cdot 0$ & 262 & $\begin{array}{l}2.0 \\
1.8\end{array}$ & $\begin{array}{l}326 \\
350\end{array}$ \\
\hline $2 \cdot 6$ & 292 & $2 \cdot 5$ & 272 & 0.8 & 321 & 0.2 & 267 & $\begin{array}{l}4 \cdot 3 \\
1 \cdot 4\end{array}$ & $\begin{array}{l}353 \\
360\end{array}$ \\
\hline $3 \cdot 0$ & 273 & $5 \cdot 5$ & 277 & $1 \cdot 1$ & 340 & $3 \cdot 4$ & 287 & $\begin{array}{l}1 \cdot 6 \\
3 \cdot 1\end{array}$ & $\begin{array}{l}414 \\
450\end{array}$ \\
\hline $4 \cdot 4$ & 275 & $3 \cdot 1$ & 361 & 0.5 & 365 & $4 \cdot 7$ & 315 & $2 \cdot 5$ & 458 \\
\hline $1 \cdot 9$ & 293 & $4 \cdot 9$ & 373 & 0.5 & 410 & $2 \cdot 5$ & 338 & $\begin{array}{l}2 \cdot 9 \\
2 \cdot 1\end{array}$ & $\begin{array}{l}462 \\
469\end{array}$ \\
\hline $5 \cdot 4$ & 453 & 81 & 618 & $3 \cdot 1$ & 676 & $1 \cdot 6$ & 453 & $\begin{array}{l}4 \cdot 0 \\
1 \cdot 3\end{array}$ & $\begin{array}{l}487 \\
489\end{array}$ \\
\hline 0.3 & 481 & $10 \cdot 0$ & 649 & & & $4 \cdot 3$ & 462 & 1.0 & 498 \\
\hline $1 \cdot 2$ & 506 & $4 \cdot 1$ & 802 & & & $\begin{array}{l}3 \cdot 1 \\
4 \cdot 2 \\
1 \cdot 0 \\
4 \cdot 3\end{array}$ & $\begin{array}{l}613 \\
664 \\
694 \\
839\end{array}$ & $\begin{array}{l}6 \cdot 5 \\
0 \cdot 9 \\
1 \cdot 4 \\
6 \cdot 2 \\
5 \cdot 0 \\
1 \cdot 4 \\
5 \cdot 6\end{array}$ & $\begin{array}{l}510 \\
511 \\
556 \\
564 \\
596 \\
680 \\
781\end{array}$ \\
\hline All ori & $\overbrace{-35 \cdot 0 \mathrm{~cm}}$ & $\begin{array}{l}\text { All or } \\
\$ 34 \cdot 9-\end{array}$ & $\overline{\operatorname{ginally}}_{-36.5 \mathrm{~cm} .}$ & All ori & $\overbrace{-42 \cdot 7 \mathrm{~cm}}$ & All or & $\underbrace{}_{-33 \cdot 9 \mathrm{~cm} .}$ & $\begin{array}{c}\text { All or } \\
\wp 39 \cdot 0-\end{array}$ & inally \\
\hline
\end{tabular}




\section{AN EXPERINENT IN THE TRANSPLANTATION OF PLAICE FROM}

Although the above lists are not exhaustive and the growths quoted have been taken more or less at random, it can be clearly seen how slowly North Sea plaice of the stated lengths grew, as compared with these fish transplanted from the White Sea.

As compared with the first transplanted plaice only two growths of North Sea fish are noticed to be in excess, and these individuals had been at liberty respectively twice and three times as long after marking.

Comparing the growth of E 3880 with that of similar sized North Sea fishes, we find it only surpassed by specimens which have been out twice, nearly thrice, four and a half, and nearly six times as long.

No growth is observed to equal that shown in the case of $\mathrm{E} 3884$, 3893 , or 3875 , though some of the periods of liberty are more than twice as long.

These growths are truly remarkable, in consideration of the probable age of the specimens concerned, and in view of the slow growth old plaice have been frequently shown to display.

It may be mentioned that further, but incomplete, investigations of the otoliths of the smallest plaice yet found on the White Sea grounds amply bear out the indications of slow growth afforded in my earlier report.

2. InCREase in Weight.-All the fish have been weighed after their recovery by the fishermen, but, as the relation between length and weight of White Sea plaice in their normal condition is unknown at present, it is not possible to state exactly by how much the last five individuals have increased their bulk. In view of the additions which have been demonstrated as regards length, and in view of the fattened condition of the fish, the weight increments must have been very considerable. A tentative estimate can be deduced from the following data.

The weights of the eight fish caught in July compared with the average weight of Dogger plaice of the same sizes determined by Masterman* show deficiencies amounting to $17 \cdot 3,23 \cdot 5,41 \cdot 5,38 \cdot 1,29 \cdot 1$, $31 \cdot 0,22 \cdot 9$, and $26 \cdot 8$ per cent respectively. The average deficit amounts to just under $29 \%$.

It cannot at present be said how closely this determination displays the actual deficiency in condition for which the White Sea plaice are noted, but it at least has the merit of bearing out the experience of practical men as to the inferiority of these fish as compared with those from the North Sea.

* Report on the Research Work of the Board of Agriculture and Fisheries in relation to the Plaice Fisheries of the North Sea. Cd. 4738. London, 1909. 
I propose to estimate the increase in weight of the five fish referred to on two bases:-

A. That the original weight of each fish was equal to that of a normal Dogger plaice.

B. That the weights thus obtained (A) are on an average $29 \%$ too high, as was ascertained for the July fish.

Estimate A for the original weight being obviously too high, we can be satisfied that any increase shown on this basis is below that actually attained. It is further possible that increments based on Estimate B understate those actually attained.

The resulting figures are given in Table III below.

\section{TABLE III.}

Table showing estimated increase in the weight of five plaice transplanted from the White Sea to the North Sea, based on two estimates of their original weight.

A. That the plaice were equal in weight to Dogger plaice of corresponding sizes.

B. That estimate A gives an original weight value $29 \%$ too high in accordance with observations made on eight fish in July.

\begin{tabular}{|c|c|c|c|c|c|c|c|}
\hline \multirow{2}{*}{ Number. } & \multicolumn{2}{|c|}{ Estimated Original Weight. } & \multirow{2}{*}{$\begin{array}{c}\text { Determined } \\
\text { Ultimate Weight. }\end{array}$} & \multicolumn{2}{|c|}{ Increase in Weight. } & \multicolumn{2}{|c|}{$\%$ Increase. } \\
\hline & A. & B. & & Estimate A. & Estimate B. & Est. A. & Est. B. \\
\hline E. & grammes. & grammes. & grammes. & grammes. & grammes. & $\%$ & $\%$ \\
\hline $\begin{array}{l}3876 \\
3880 \\
3884 \\
3893 \\
3875\end{array}$ & $\begin{array}{l}485 \\
528 \\
843 \\
405 \\
813\end{array}$ & $\begin{array}{l}344 \\
375 \\
599 \\
288 \\
577\end{array}$ & $\begin{array}{r}590 \\
742 \\
1095 \\
702 \\
1535\end{array}$ & $\begin{array}{l}105 \\
214 \\
252 \\
297 \\
722\end{array}$ & $\begin{array}{l}246 \\
367 \\
496 \\
414 \\
958\end{array}$ & $\begin{array}{l}21 \cdot 6 \\
40 \cdot 5 \\
29 \cdot 9 \\
73 \cdot 3 \\
88 \cdot 8\end{array}$ & $\begin{array}{r}71 \cdot 5 \\
97 \cdot 6 \\
82.8 \\
143 \cdot 7 \\
166.0\end{array}$ \\
\hline
\end{tabular}

From this table it can be seen that, on the lowest possible estimate, the two fish which had been at liberty the longest (and this period less than a year and including a winter) had increased by about threequarters of their original weight $(73.3 \%$ and $88.8 \%)$; the fish which had been at liberty shorter periods also displaying corroborative increments.

The data are too small to permit of further discussion, but by kind permission of my colleague, Dr. Wallace, I am able to put forward in contrast to the above figures data from his forthcoming report.

Dr. Wallace finds from otolith investigations that, as regards the plaice of the Dogger and Flamborough region, the weight of six-year- 
old males (average size $37.0 \mathrm{~cm}$.) shows an increment of less than $30 \%$ on that of those five years old, whilst the seven-year-old fish of this sex, having an average length of $38.1 \mathrm{~cm}$., show less than $10 \%$ weight increment on fish a year younger. This oldest group is, however, not sufficiently well represented for this result to be regarded as more than approximate.

Dealing with the females, the six-year-old fish (average size $41 \cdot 0 \mathrm{~cm}$.) are found to average a little over $40 \%$ heavier than those of five years, and the seven-year-old fish (average size $44.1 \mathrm{~cm}$.) show an increment of just over $20 \%$ as compared with the six-year-olds.

Referring these figures, which are based on abundant material, back to the percentage weight increments of Estimate A in Table III, the indications in this table present a truly remarkable contrast in favour of the probably older plaice transplanted from the White Sea.

3. Increase in Value.-The plaice fishery in the Barents Sea has only been conducted by our trawlers during four summers, and it would be premature to discuss the values of the product. These, however, have been adversely affected by two important considerations, the somewhat poor quality of the fish combined with excessive supplies in the summer months.

A trade expert giving evidence before the Committee on Fishery Investigations expressed an opinion that the plaice sell at less than onetenth the value of any other plaice (Committee on Fishery Investigations, 1908. Minutes, Cd. 4304, p. 391).

The White Sea plaice have not the coarse, dark appearance, which used to characterize the old, accumulated stock at Iceland, and would, after a few months fattening in the North Sea, be indistinguishable in external appearance and doubtless too in food value from the indigenous population. Thus, if we may assume that each of the last five fish would have doubled its weight had it been at liberty a year, and basing the value of White Sea plaice at one-fifth that of North Sea plaice, each would have been worth at least ten times the price usually obtained.

It would be absurd, on the slender though corroborative evidence of the above results, to suggest that the transplantation of White Sea plaice would be practicable as a commercial undertaking. At the same time it must be admitted that even this would prove sounder economy as regards the development of the White Sea fishery than is the present plan of converting many tons of this valuable fish species into manure, as was done in the great gluts in the summer of 1909 .

The fact that plaice can be carried in safety such long distances and through such varying conditions, broadens the question of trans- 
THE BARENTS SEA ("WHITE SEA") TO THE NORTH SEA. 511

plantation. Might not, for instance, plaice be carried across the Atlantic and introduced to the Canadian coasts and the Banks of Newfoundland, where its congeners in other waters, the cod, haddock, and halibut, already occur? Or, again, might not the very small halibut, which have been brought to market by the trawlers in vast quantities from certain parts of Faxe Bay, Iceland, also be brought alive and set out on the North Sea grounds, where this valuable species was without a doubt much more abundant formerly than it is to-day? Such, and many practical questions of a similar nature, proffer a wide field for future research. 